\title{
Stomatal Characterization of Grass Leaves by Four Preparation Techniques
}

\author{
Val J. Anderson \\ val_anderson@byu.edu \\ John S. Gardner \\ Joyce Phillips Hardy
}

Follow this and additional works at: https://scholarsarchive.byu.edu/facpub

Part of the Animal Sciences Commons, and the Plant Sciences Commons

Original Publication Citation

Microscopy and Microanalysis 1.3(Jun1995): 131-135.

\section{BYU ScholarsArchive Citation}

Anderson, Val J.; Gardner, John S.; and Hardy, Joyce Phillips, "Stomatal Characterization of Grass Leaves by Four Preparation Techniques" (1995). Faculty Publications. 688.

https://scholarsarchive.byu.edu/facpub/688

This Peer-Reviewed Article is brought to you for free and open access by BYU ScholarsArchive. It has been accepted for inclusion in Faculty Publications by an authorized administrator of BYU ScholarsArchive. For more information, please contact ellen_amatangelo@byu.edu. 


\title{
Stomatal Characterization of Grass Leaves by Four Preparation Techniques
}

\author{
Joyce Phillips Hardy, ${ }^{1 *}$ Val Jo Anderson, ${ }^{2}$ and John S. Gardner ${ }^{3}$ \\ ${ }^{1}$ School of Science and Mathematics, Chadron State College, Chadron, NE 69337; ${ }^{2}$ Dept. of Botany and Range Science, \\ Brigham Young University, Provo, UT 84602; ${ }^{3}$ Microscopy Laboratory, Brigham Young University, Provo, UT $84602^{1}$
}

\begin{abstract}
Four leaf preparation techniques (air drying, tetramethylsilane air drying, critical point drying, and freeze substitution) used in scanning electron microscopy (SEM) were evaluated with respect to the degree of cellular distortion they produce in stomatal guard cells of leaves of Dactylis glomerata and Elymus canadensis. Surface morphological distortion and cuticle disruption in the air-dried and tetramethylsilane air-dried leaves, and cuticle disruption within the critical point-dried tissue made it difficult to obtain measurements. The freeze-substituted tissue experienced little cuticle disturbance, and the cellular morphology appeared normal. The length of the guard cells did not significantly differ between the air-dried, tetramethylsilane air-dried, critical point-dried, or freeze-substituted samples. Widths did significantly vary, with the freeze-substituted tissue having lower values than tissues treated with the other treatments. Freeze substitution methodology produced SEM images that appear to be less distorted and allow easy and precise measurement.
\end{abstract}

KEY WORDS: stomata, grass leaves, preparation technique.

\section{INTRODUCTION}

Ecological studies on drought tolerance and biomass production have attempted to correlate stomatal size and/or density to drought tolerance (Redman, 1985; Anderson and Briske, 1990; Hardy, Anderson and Gardner, 1995). Lower stomatal density, with a corresponding higher stomatal resistance, may be one means by which grasses achieve crop water economy under drought stress (Ezekial et al., 1989). Techniques for studying stomatal size traditionally have included epidermal peels (Gorton et al., 1989; Weyers and Travis, 1981), leaf scrapes to remove all but the surface in question (Anderson and Briske, 1990), plastic replicas utilizing fingernail polish (Charlton, 1988), silicon rubber (Dobrenz et al., 1969; Smith et al., 1989), nitrocellulose (Shearman and Beard, 1972), vinyl film (Horanic and Gardner, 1967), and clearing the leaf by boiling (Clarke, 1960; Teare et al., 1971; Tan and Dunn, 1975). The resulting surfaces or replicas were then viewed using light microscopy. During the making of leaf replicas and after clearing, leaf segments are allowed to dehydrate. The assumption that no surface distortion takes place is critical to the determination of stomatal density and size using the above techniques.

* Corresponding author: Joyce Phillips Hardy, School of Science and Mathematics, Chadron State College, 10th and Main, Chadron, NE 69337.

Revised version of an article published earlier in Microscopy: The Key Research Tool.
SEM preservation techniques for botanical tissue include air drying without pretreatment, air drying from an organic solvent (freon, acetone, ethanol, tetramethylsilane, etc.), critical point drying (standard fixation and dehydration, freeze substitution), freeze drying, and low-temperature direct observation of the frozen specimens (Postek et al., 1980; Steinbrecht, 1980; Nordestagaard and Rostgaard, 1985; Dawes, 1988; Scheidegger et al., 1991). Although it is well established that low-temperature SEM generally provides superior images (Read and Jeffree, 1991), some samples require careful critical point drying in order to reduce artefacts (Mycock and Berjak, 1991).

Previous studies have attempted to correlate stomatal characteristics (i.e., size) with ecological conditions such as moisture regime and biomass production. To date, no distinct correlation has been found, but the underlying assumption that no or minimal distortion takes place during specimen preparation has not been examined. The evaluation of SEM techniques presented here is an attempt to determine the best method for grass foliar preparation to allow stomatal quantification.

\section{Methods}

Species chosen for the analysis were Dactylis glomerata L. (Orchardgrass) and Elymus canadensis L. (Canadian wildrye). These plants were collected from the Nebraska Sandhills region during August 1989 and 
transplanted into the Brigham Young University greenhouse, where they were maintained with adequate water and two N-P-K fertilizer treatments prior to leaf collection during the spring of 1991. The uppermost fully expanded culm leaf of four different plants per species was selected for analysis during an early afternoon with bright sunshine. Adjacent central $1 \mathrm{~cm}$ lengths of each leaf of these four plants were randomly assigned to the treatments. The upper right-hand corners of the leaf segments were notched to facilitate leaf surface differentiation, and treatments were as follows:

1. Air-dried $(A D)$ - leaf segments were placed in open vials and stored at ambient conditions for $10 \mathrm{~d}$.

2. Tetramethylsilane (TMS) - leaf segments were placed into buffered glutaraldehyde/acrolein fixative (2\% glutaraldehyde, $3 \%$ acrolein, $0.1 \mathrm{M}$ sodium cacodylate buffer at $\mathrm{pH}$ 7.2-7.4) for $10 \mathrm{~d}$, dehydrated through a standard series of ethanol (Hess, 1966), and transferred to tetramethylsilane for two 10 -min exchanges. The leaf segments were then allowed to air day (Dey et al., 1989).

3. Standard critical point dried (CPD) - leaf segments were treated as above through the series of ethanol dehydration, then rinsed with $100 \%$ ethanol and critical point dried from $\mathrm{CO}_{2}$ (Cohen, 1974; Ruffolo, 1974; Postek et al., 1980; Dawes, 1988).

4. Freeze substitution (FS) - leaf segments were plunged into freon 22 (monochlorodifluoromethane $-146^{\circ} \mathrm{C} \mathrm{m}$. p.) at its melting point immediately following harvest. After freezing, they were transferred to liquid nitogen for holding until all of the harvesting of that species was complete. The samples were then transferred to $1 \% \mathrm{OsO}_{4}$ in dry acetone at $-80^{\circ} \mathrm{C}$ and maintained at this temperature for 10 days. The tissue was brought to room temperature, washed once in dry acetone and dry $100 \%$ ethanol, and processed through critical point drying (Hardy and Gardner, 1991).

After preparation as above, the leaf segments were mounted on aluminum stubs and approximately $40 \mathrm{~nm}$ gold was applied. Specimens were examined with a JEOL $840 \mathrm{~A}$ scanning electron microscope at $10 \mathrm{kV}$. Measurements were taken from the abaxial (lower) surface in Dactylis glomerata and the adaxial (upper) surface in Elymus canadensis. Quantification of lengths and widths in microns was completed utilizing a Quantel Crystal Unit (Link Analytical, Madison, WI) calibrated to a micron standard. Lengths of stomatal guard cell apparatus were measured from the outer junction point of the two guard cells at each end of the stomata, parallel to the stomatal slit. Widths were measured at the widest part of the stomata, perpendicular to the stomatal slit. One stomatal complex from each margin of each leaf segment and four stomata distributed across the central section of the leaf were arbitrarily selected and measured. Values from the six stomata were averaged to standardize the estimation of stomatal lengths and widths. Four leaf segments per species were evaluated. The measurements were analyzed using standard analysis of variance techniques (Peterson, 1985; Ott. 1988).

\section{Results}

Differences in the retention of cell structure morphology were evident between the treatment methods. Air drying and treatment with tetramethylsilane both resulted in lateral compression of the cells as viewed from the surface (Figures 1, 2, 5, and 6). This may be due to the collapse of the rounded cell walls and the resultant formation of wrinkles or because of strains arising as a result of physical constraints within the drying leaf. After both of these treatments, leaves also exhibited severe cracking of the cuticle (Figures 1, 2, 5, and 6). No difference in Dactylis glomerata or Elymus canadensis guard cell lengths were found in comparing TMS and AD tissue, although widths did differ (Table 1). This lab and others (Dey et al., 1989) have successfully used TMS on other samples; the grass leaves utilized in this study apparently do not lend themselves well to this treatment method.

Critical point drying is commonly used as the method of choice for preparing tissues for the SEM (Cohen, 1974; Ruffolo, 1974; Postek et al., 1980). Tissues processed through CPD (Figures 3 and 7) showed much less distortion of surface morphology than the air-dried or TMS-treated tissue, although cuticle fragmentation was evident. Dactylis glomerata guard cells that had been CPD did not differ in length from the $\mathrm{AD}$ - or TMS-treated tissue, although they were longer than those prepared by FS. Widths were similar to samples treated with TMS, but dissimilar to AD and FS treated tissues (Table 1).

Freeze-substituted tissue displayed little surface or cuticle disruption (Figures 4 and 8) An additional feature observed was open stomata, whereas in the other treatments the stomatal apertures were generally closed or nearly closed. This property of the FS-treated tissue suggests little cellular distortion or modification from the in situ condition. Where present, cuticle disruption occurred in very small localized areas. Leaf surface morphology appeared as expected. Dactylis glomerata guard cell lengths, while not statistically significant ( $\mathrm{p}$ $=0.27$ ), appeared to be shorter with FS. Stomatal widths were significantly less in FS leaves when compared with TMS and CPD. Elymus canadensis FS tissue tended to be smaller in guard cell length but were significant only at $\mathrm{p}=0.28$ (Table 1 ).

\section{DISCUSSION}

The goals of specimen processing are twofold: (1) to preserve cellular structure with minimal alteration 

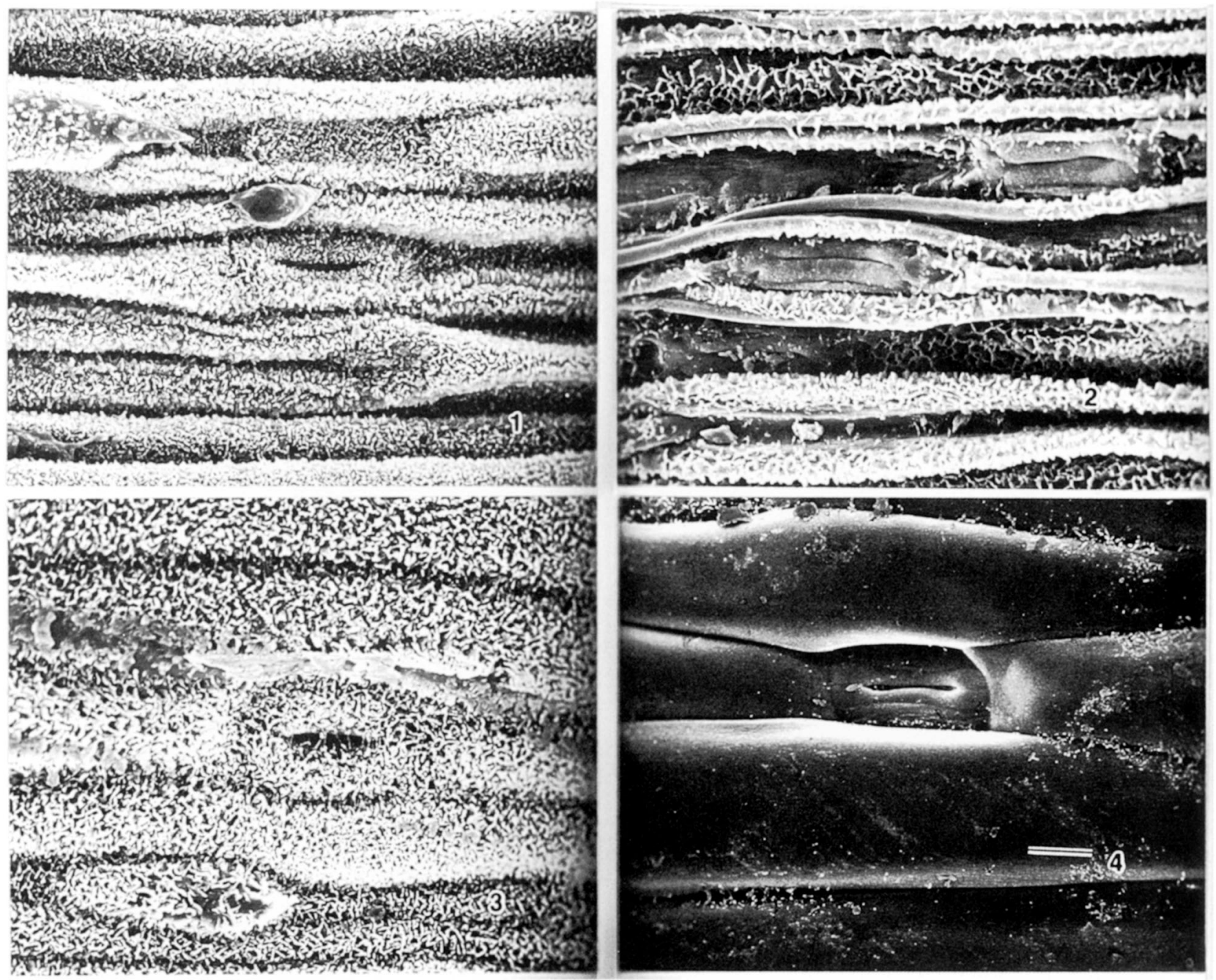

Figures 1-4. Scanning electron micrographs of Dactylis glomerata L. leaves at 1000X. The bar on Figure 4 is $10 \mu \mathrm{m}$ and is applicable to Figures 1 to 4 . Figure 1. Tissue was air dried. Note the severe shrinkage; Figure 2. Tissue was tetramethylsilane treated and air dried. Note the apparently closed stomata; Figure 3. Tissue was processed through standard critical point drying. Note the severe cracking of the cuticle; Figure 4. Tissue was freeze substituted. Note the clean surface and the turgid cells.

from the living state, and (2) to present morphological characteristics of the cell with a minimum of distortion or disruption from the living state (Dawes, 1988). This investigation dealt with methods of tissue preparation, specifically guard cells surrounding stomata, as a means of determining cellular distortion. The alterations, which occurred in air-dried and TMS-treated tissues, made it extremely difficult to measure the lengths and widths of cells and the exact location of the cellular junctions was obscured. Depending on the direction in which the outer wall fold layed, this junction was often covered and unobservable. As a result, many of the arbitrary selected stomata could not be used for measurement, thereby potentially biasing the results. Another potentially disruptive consequence of these preparation techniques was the cracked and peeling cuticle. In some areas this damage to the cuticle resulted in extremely cluttered viewing and shadowing of the cellular structures, thereby potentially increasing errors in surveying.

\section{TABLE 1}

Comparison of stomatal complex sizes of two grasses treated by four different techniques: air dried (AD), tetramethylsilane (TMS), critical point dehydration (CPD), and freeze substituted (FS). Level of significance of differences was derived from analysis of variance statistical techniques

\begin{tabular}{lccccc}
\hline Dactylis glomerata & $\mathrm{AD}$ & $\mathrm{TMS}$ & $\mathrm{CPD}$ & $\mathrm{FS}$ & $\mathrm{p} \leq$ \\
\hline Length & 29.53 & 29.83 & 32.38 & 27.06 & .270 \\
Width & $7.71 \mathrm{c}$ & $6.13 \mathrm{~b}$ & $5.97 \mathrm{~b}$ & $5.00 \mathrm{a}$ & .001 \\
Length * Width & $228.07 \mathrm{~b}$ & $182.62 \mathrm{ab}$ & $193.93 \mathrm{~b}$ & $134.83 \mathrm{a}$ & .009 \\
\multicolumn{7}{l}{ Elymus canadensis } & & & & & \\
Length & 36.84 & 37.87 & 37.15 & 34.72 & .279 \\
Width & $7.73 \mathrm{~b}$ & $6.31 \mathrm{a}$ & $6.59 \mathrm{a}$ & $6.33 \mathrm{a}$ & .001 \\
Length * Width & $284.60 \mathrm{~b}$ & $239.14 \mathrm{a}$ & $244.32 \mathrm{ab}$ & $220.00 \mathrm{a}$ & .004
\end{tabular}

Note: Similar letters within the row indicate no significant difference at alpha $=.05$ 

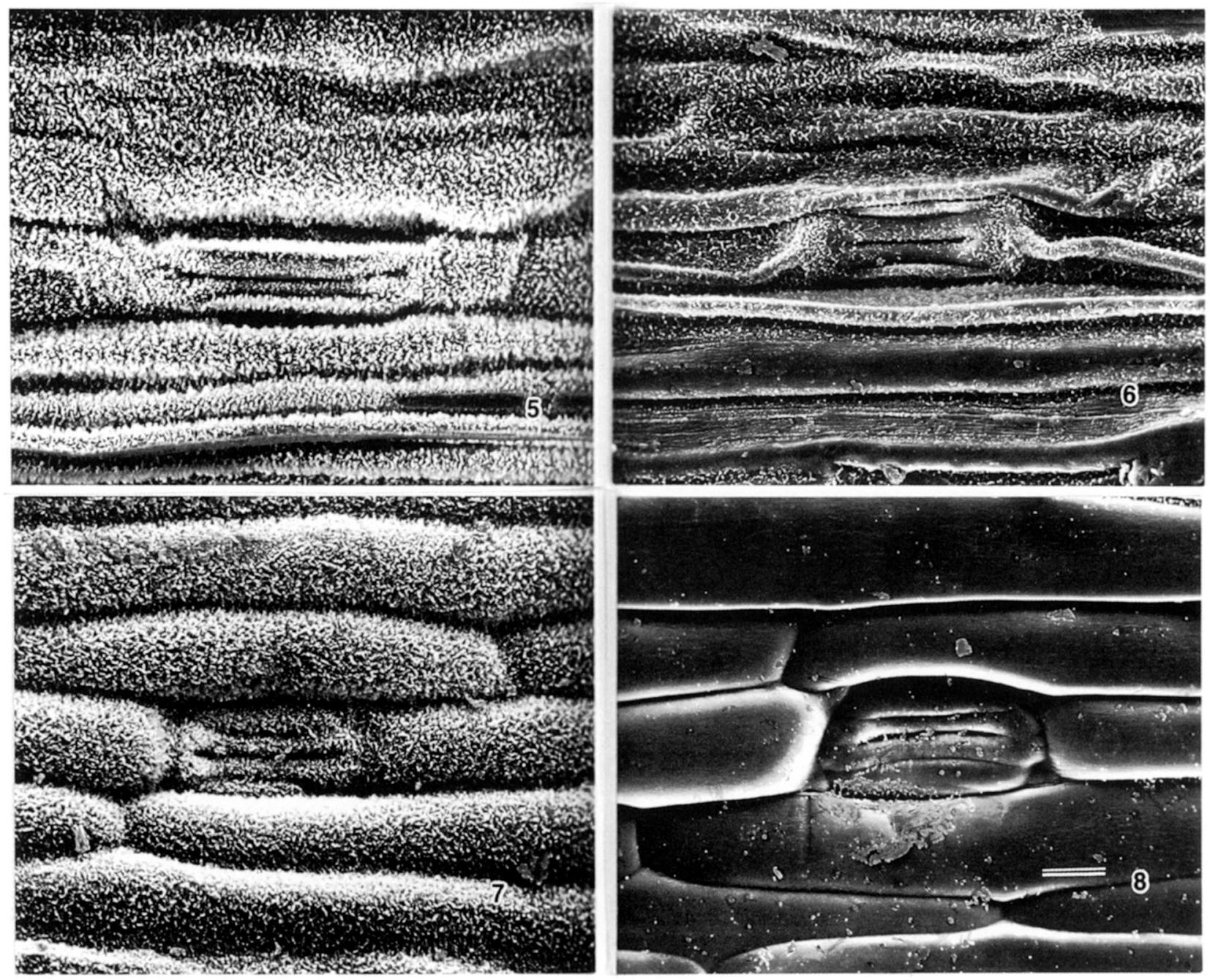

Figures 5-8. Scanning electron micrographs of Elymus canadensis L. leaves at 1000X. The bar on Figure 8 is $10 \mu \mathrm{m}$ and is applicable to Figures 5 to 8. Figure 5. Tissue was air dried. Note the severe shrinkage and cracked cuticle; Figure 6. Tissue was tetramethylsilane treated and air dried. Note the collapsed cell walls; Figure 7. Tissue was processed through standard critical point drying. Note the apparently turgid cells and the severe cracking of the cuticle; Figure 8. Tissue was freeze substituted. Note the relatively clean surface and the turgid cells.

Guard cell widths differed significantly $(p<0.001$ in both species) between treatments. Differences of over 9\% in guard cell lengths were recorded between TMS and FS leaves. At traditionally accepted statistic levels $\mathrm{p}$ $\leq 0.05$ ), these differences are non-significant ( $p=0.270$ in Dactylis glomerata, $p=0.270$ in Elymus canadensis). However, a definite trend toward guard cell length and width differences between the treatments is evident in both species. Variation in the environment at the time of stomatal development and/or enlargement would cause differences in guard cell size. This variation cannot be distinguished from the other causes inherent in the experiment and therefore is included in the statistical experimental error. This results in an increased experimental error and therefore decreased sensitivity in the analysis. A p $<0.3$ for stomatal length in both species indicates an expected difference between treatments $70 \%$ of the time.
Closed guard cells form approximately a rectangular shape, with slightly bulbous ends. Therefore, multiplying length by width of guard cells yields an overall size indication of the guard cell apparatus and potential aperture. Analysis of length $\mathrm{X}$ width revealed figures that were highly significant (Table 1: Dactylis glomerata $p=0.009 ;$ Elymus canadensis $p=0.004)$. In Dactylis glomerata the freeze-substituted tissue was significantly smaller than the others. In Elymus candadensis the airdried tissue was significantly larger than the others; although the freeze-substituted guard cells were numerically smaller, the statistical analysis did not reveal differences at alpha $=0.05$.

Air-dried and tetramethylsilane-treated tissues exhibited severe distortion of the surface morphology, which made measurements difficult and seemed to enlarge or stretch the tissue, relative to tissue prepared by FS. Critical point-dried tissue exhibited cuticle dis- 
tortion that made surveying difficult. All three preparation methods (air-dried, tetramethylsilane air-dried, and standard critical point-dried) yielded tissues that showed closed stomata when viewed, revealing that some change in guard cell osmotic pressure had occurred during initial processing of the tissue.

Based on the goals presented at the beginning of this section, the TMS and AD tissue do not meet the objectives set forth for grass foliar tissue preparation techniques. Critical point-dried tissues present a better appearance in cellular morphology than the TMS- and $\mathrm{AD}$-prepared tissues, but there are still apparent problems as evidenced by the cracked cuticle and closed stomata. The freeze-substituted tissue appeared to have the least cellular and morphological distortion, and therefore achieved the criteria for preparation techniques more closely than the air-dried, tetramethylsilane- and critical point-dried procedures. Utilization of freeze-substituted tissue for analysis of grass foliar leaf characteristics such as stomatal measurements is recommended.

\section{REFERENCES}

Anderson, V.J. and Briske, D.D. (1990) Stomatal distribution, density and conductance of three perennial grasses native to the southern true prairie of Texas, Am. Midland Naturalist, 123, 152-159.

Charlton, W.A. (1988) Stomatal pattern in four species of monocotyledons, Annu. Botany, 61, 611-621.

Clarke, J. (1960) Preparation of leaf epidermis for topographic study, Stain Technol., 35, 35-39.

Cohen, A.L. (1974) Critical point drying: pp. 44-112 in Principles and Techniques of Scanning Electron Microscopy, ed. by M.A. Hyat. Van Nostrand Reinhold Co.

Dawes, C.J. (1988) Introduction to biological electron microscopy: pp. 73-120. Ladd Research Industries, Inc., Burlington, Vermont.

Dey, S., Basu Baul, T.S., Roy, B., and Dey, D. (1989) A new rapid method of air-drying for scanning electron microscopy using tetramethylsilane, J. Microscopy, 156, 259-261.

Dobrenz, A.K., Wright, L.N., Humphrey, A.B., Massengale, M.A., and Kneebone, W.R. (1969) Stomate density and its relationship to water-use efficiency of blue panicgrass (Panicum antidotale Retz.), Crop Sci., 9, 354-357.

Ezekial, R., Perumal, N.K., and Sukumaran, N.P. (1989) Stomatal density, stomatal resistance, and photosynthetic rate in potato cultivars, Photosynthetica, 23, 671-673.

Gorton, H.L., Williams, W.E., Binns, M.E., Gemmell, C.N., Leheny, E.A., and Shepherd, A.C. (1989) Circadian stomatal rhythms in epidermal peels from Vicia faba, Plant Physiol., 90, 1329-1334.

Hardy, J.P., Anderson, V.J., and Gardner, J.S. (1995) Stomatal characteristics, conductance ratios, and drought-induced leaf modifications of semiarid grassland species, Am. J. Bot., 82, $1-7$.
Hardy, J.P. and Gardner, J.S. (1991) Grass leaf stomata preparation techniques for scanning electron microscopy: Proceedings of the 49th Annual Meeting of the Electron Microscopy Society of America, pp. 220-221.

Hess, W.M. (1966) Fixation and staining of fungus hyphae and host plant root tissues for electron microscopy, Stain Technol., 41, 27-35.

Horanic, G.E. and Gardner, F.E. (1967) An improved method of making epidermal imprints, Bot. Gazette, 128, 144-150.

Mycock, D.J. and Berjak, P. (1991) In defense of aldehydeosmium fixation and critical-point drying for characterization of seed-storage fungi by scanning electron microscopy, $J$. Microscopy, 163, 321-331.

Nordestgaard, B.G. and Rostgaard, J. (1985) Critical-point drying versus freeze drying for scanning electron microscopy: A quantitative and qualitative study on isolated hepatocytes, $J$. Microscopy, 137, 189-207.

Ott, L. (1988) An Introduction to Statistical Methods and Data Analysis, 3rd ed: pp. 401-415. PWS-Kent Publishing Co., Boston, MA.

Peterson, R.G. (1985) Design and Analysis of Experiments: pp. 118-166. Marcel Dekker, New York, NY.

Postek, N.T., Howard, K.S., Johnson, A.H., and McMichael, K.L. (1980) Scanning electron microscopy: A Student's Handbook. Michael T. Postek, Jr. and Ladd Research Industries, Inc.

Read, N.D. and Jeffree, C.E. (1991) Low-temperature scanning electron microscopy in biology, J. Microscopy, 161, 5972.

Redmann, R.E. (1985) A simple technique for making epidermal imprints using clear vinyl film, Can. J. Bot., 63, 16691670.

Ruffolo, J.J. (1974) Critical point drying of protozoan cells and other biological specimens for scanning electron microscopy. Apparatus and methods of specimen preparation, Trans. Am. Micros. Soc., 93, 124-131.

Scheidegger, C., Guenthardt-Goerg, M., Matyssek, R., and Hatvani, P. (1991) Low-temperature scanning electron microscopy of birch leaves after exposure to ozone, $J$. Microscopy, 161, 85-95.

Shearman, R.C. and Beard, J.B. (1972) Stomatal density and distribution in Agrostis as influenced by species, cultivar, and leaf blade surface and position, Crop Sci., 12, 822-823.

Smith, S., Weyers, J.D.B., and Berry, W.G. (1989) Variation in stomatal characteristics over the lower surface of Commelina communis leaves, Plant, Cell Environ., 12, 822823.

Steinbrecht, R.A. (1980) Cryofixation without cryoprotectants, freeze substitution, and freeze etching of an insect olfactory receptor, Tiss. Cell, 12, 73-100.

Tan, G-Y. and Dunn, G.M. (1975) Stomatal length, frequency, and distribution in Bromus inermis Leyss, Crop Sci., 15, 283286.

Teare, I.D., Peterson, C.J., and Law, A.G. (1971) Size and frequency of leaf stomata in cultivars of Triticum aestivum and other Triticum species, Crop Sci., 11, 496-498.

Weyers, J.D.B. and Travis, A.J. (1981) Selection and preparation of leaf epidermis for experiments on stomatal physiology, J. Exp. Bot., 32, 837-850. 